Bayero Journal of Pure and Applied Sciences, 10(1): 368 - 371

ISSN $2006-6996$

\title{
EVALUATION OF ANTICONVULSANT ACTIVITIES OF ETHANOL LEAF EXTRACT OF Hymenocardia acida TUL (EUPHORBIACEAE) IN MICE AND CHICKS
}

\author{
Wada, A.S. ${ }^{* 1}$, Yaro, A.H. ${ }^{1}$, Aliyu, M. ${ }^{1}$, Danjuma, N.M. ${ }^{2}$ and Mohammed, M. ${ }^{3}$ \\ ${ }^{1}$ Department of Pharmacology and Therapeutics, Bayero University, Kano \\ ${ }^{2}$ Department of Pharmacology and Therapeutics, Ahmadu Bello University, Zaria \\ ${ }^{3}$ Department of Clinical Pharmacy and Pharmacy Practice, Ahmadu Bello University, Zaria \\ *Corresponding Author: +234-805-4077519; pharmwada17@gmail.com.
}

\section{ABSTRACT}

The aim of the research is to investigate the anticonvulsant property of ethanol leaf extract of $H$. acida (ELHA) in mice and chicks. The work employed maximal electroshock test (MEST) in chicks, pentylenetetrazole (PTZ), 4-aminopyridine (4-AP) and strychnine-induced convulsion in mice. The results showed the intraperitoneal $L D_{50}$ of $E L H A$ to be $3808 \mathrm{mg} / \mathrm{kg}$ in mice. The extract produced no significant effect on mean recovery time in MEST. ELHA at 250 and 500 $\mathrm{mg} / \mathrm{kg}$ protected $50 \%$ of mice against seizures by $4-A P$. ELHA at $1000 \mathrm{mg} / \mathrm{kg}$ produced significant $(p<0.05)$ increase in mean onset of seizures induced by $4-A P$. ELHA at $500 \mathrm{mg} / \mathrm{kg}$ protected $33.3 \%$ of mice against PTZ induced convulsion, however no significant effect was observed on mean onset of seizures induced by PTZ and strychnine. Phytochemical screening revealed the presence of alkaloids, steroids, glycosides, saponins, tannins and flavonoids. In conclusion, results revealed that the ethanol leaf extract of $\mathrm{H}$. acida possess bioactive compounds that could be useful in the management of epilepsy.

Keywords: Hymenocardia acida, MEST, PTZ, 4-AP, Strychnine

\section{INTRODUCTION}

About 50 million people worldwide have epilepsy of which nearly $80 \%$ are found in developing countries. Epilepsy is a major neurological disorder that accounts for $0.75 \%$ of the global burden of disease (WHO, 2016).

Hymenocardia acida (Euphorbiaceae) is very popular in African Traditional medicine. It is called "Heart-fruit" in English, "jan yaro" in Hausa, "yawa satoje" in Fulani, "ikalaga" in Igbo, and "Orunpa" in Yoruba, "Uchuo" in Igede, "enanche" in Idoma. Hymenocardia acida is a dioecious tree up to 6-10 m tall, often stunted. It is found in Savanna region of Nigeria. $H$. acidahas been used in folk medicine for many years in Nigeria and some other parts of Tropical Africa. The leaves, bark and roots of $H$. acida are used either in infusion or powdered form to treat hypotension, diabetes, sickle cell, epilepsy, schizophrenia (Dalziel, 1937). The work investigated the anticonvulsant potential of ethanol leaf extract of $H$. acida in mice and chicks.

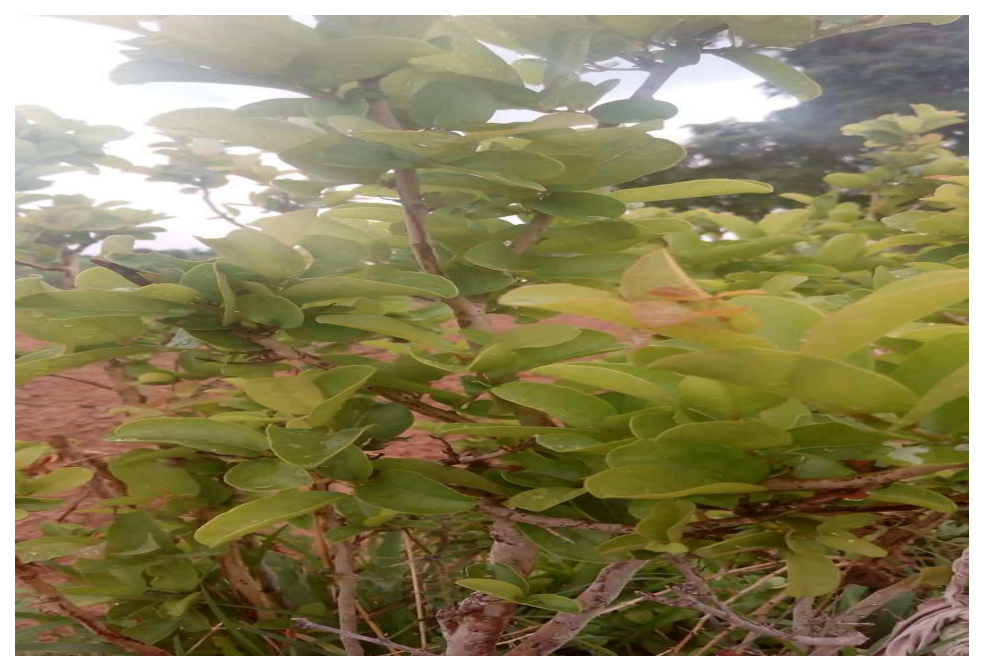

Plate I: Hymenocardia acida in its natural habitat (Zaria, Nigeria) 


\section{MATERIALS AND METHODS}

Leaves of Hymenocardia acida were collected from Dajin tohu around Shika dam, Zaria in the month of June, 2015, identified and authenticated by a taxonomist with the Department of Biological sciences, Ahmadu Bello University, Zaria by comparing with specimen voucher (number 1275) already deposited in the herbarium.

Albino mice (21 to $25 \mathrm{~g}$ ) and one day old ranger cockerels obtained from the Animal House of the Department of Pharmacology and Therapeutics, ABU, Zaria and National Animal Production and Research Institute (NAPRI), Shika Zaria respectively were used for the study. Chemicals such as Pentylenetetrazole (Sigma chemical Co. St Louis, USA), 4aminopyridine (Merck-Schuchardt, Germany) and Strychnine (Sigma Chemical Co. St Louis, USA) were the chemical agents used to induce seizure in the experimental animals. The standard drugs used for the experiment were Phenytoin sodium (Hospira, UK Limited), Phenobarbitone (Lab Renaudin, France) and Sodium valproate (Sanofi Aventis, U.S).

The ethanol leaf extract of $H$. acida, phenobarbitone, phenytoin, and sodium valproate were administered intraperitoneally. Pentylenetetrazole, 4-aminopyridine and strychnine were administered subcutaneously.

\section{Anticonvulsant Studies}

The anticonvulsant studies were carried out using electrically induced method (Swinyard and Kupferberg,1985; Browning,1992) as well as using chemical convulsants such as pentylenetetrazole (Swinyard et al.,1989), 4aminopyridine (method described by Yamaguchi and Rogawski, 1992) and Strychnine (Porter et al., 1984). Doses of 250,500 and $1000 \mathrm{mg} / \mathrm{kg}$ of the ethanol leaf extract of $H$. acida i.p were used. Normal saline $(10 \mathrm{ml} / \mathrm{kg})$ and standard drugs were used as the negative and positive control respectively.

\section{RESULTS AND DISCUSSION}

The preliminary phytochemical screening of ethanol leaf extract of Hymenocardia acida revealed the presence of alkaloids, glycosides, saponins, tannins and flavonoids among which flavonoids and saponins have been reported to possess anticonvulsant activity (Kavvadias et al., 2004) and may therefore be associated with anticonvulsant potential of the leaf extract of Hymenocardia acida.

The intraperitoneal median lethal dose $\left(\mathrm{LD}_{50}\right)$ of the ethanol leaf extract of Hymenocardia acida in mice was estimated to be $3808 \mathrm{mg} / \mathrm{kg}$ body weight suggesting that the extract is relatively less toxic according to classification of $\mathrm{LD}_{50}$ values by Matsumura, (1975) and Corbett et al., (1984).

The ethanol leaf extract of Hymenocardia acida at all doses did not protect the chicks against convulsion induced by maximal electroshock, and no significant decrease in mean recovery time of convulsed animals is observed. Whereas the standard anticonvulsant drug Phenytoin (20 $\mathrm{mg} / \mathrm{kg})$ produced significant effect $(\mathrm{p}<0.05)$ on the mean recovery time and protected $90 \%$ of the chicks against Hind Limb Tonic Extension (HLTE) induced by Maximal Electroshock Test (MEST) (Table 1). MEST is a standard AED test that evaluates the testing material's ability to protect against HLTE (DeLorenzo et al., 2001).

It is a model for generalized tonic clonic seizure, which is highly reproducible with a consistent end point (Stables and Kupferberg, 1997). Protection against HLTE also indicates the ability of a testing material to inhibit or prevent seizure discharge within the brainstem seizure substrate (Browning, 1992).

The ethanol leaf extract of Hymenocardia acida produced no significant effect on mean onset of seizures induced by PTZ in mice. The standard anticonvulsant (sodium valproate, $200 \mathrm{mg} / \mathrm{kg}$ ) gave $66.7 \%$ protection against PTZ-induced convulsion and protected $83.33 \%$ of mice from mortality (Table 2). Anticonvulsant activity in PTZ test identifies compounds that can raise the seizure threshold in the brain (Raza et al., 2001). Protection by Hymenocardia acida extract (ELHA 500) against threshold seizure induced by PTZ suggests it could be useful in the therapy of absence or myoclonic seizures.

The ethanol leaf extract at $1000 \mathrm{mg} / \mathrm{kg}$ produced significant $(p<0.05)$ increase in mean onset of convulsion induced by 4aminopyridine in mice. Phenobarbitone (20 $\mathrm{mg} / \mathrm{kg}$ ), the standard anticonvulsant used produced $100 \%$ protection against convulsion and mortality (Table 3). 4-aminopyridine is a $\mathrm{K}^{+}$ channel antagonist and it interferes with all aspect of neuronal excitability, including resting membrane potential, responsiveness to synaptic inputs, frequency adaptation and neurotransmitters release (Wickenden, 2002). The ability of the ethanol leaf and stem bark extracts of Hymenocardia acida to protect the mice from the convulsant effect of 4aminopyridine suggests that it interacts with $\mathrm{K}^{+}$ channel to produce the anticonvulsant activity. 
The ethanol leaf extract of Hymenocardia acida produced no significant effect on mean onset of seizures induced by Strychnine in Mice. Phenobarbitone $(20 \mathrm{mg} / \mathrm{kg})$ the standard anticonvulsant produced $100 \%$ protection against seizure and mortality (Table 4).Strychnine directly antagonizes the inhibitory reflexes mediated by glycine (Sayin et al., 1993).

Table 1: Effect of Ethanol Leaf Extract of Hymenocardia acida on Maximal Electroshock Test (MEST) in Chicks

\begin{tabular}{lcc}
\hline $\begin{array}{l}\text { Treatment } \\
(\mathrm{mg} / \mathrm{kg})\end{array}$ & $\begin{array}{c}\text { \%Protection } \\
\text { against seizure }\end{array}$ & $\begin{array}{c}\text { Mean recovery time } \\
\text { of seizure }(\mathrm{min})\end{array}$ \\
\hline NS $10 \mathrm{ml} / \mathrm{kg}$ & 0.0 & $9.5 \pm 1.3$ \\
ELHA $(250)$ & 0.0 & $9.1 \pm 1.3$ \\
ELHA $(500)$ & 0.0 & $8.5 \pm 0.4$ \\
ELHA (1000) & 0.0 & $12.5 \pm 1.8$ \\
PHN (20) & 90.0 & $19.0 \pm 0.0^{*}$ \\
\hline
\end{tabular}

Values are presented as Mean \pm SEM and percentages. ${ }^{*} P<0.05$, Mean recovery time of seizure compared to normal saline group using One way ANOVA followed by Dunnett's post hoc test, $\mathrm{n}=10$, NS- Normal saline, ELHA- Ethanol Leaf Extract of Hymenocardia acida, PHN- Phenytoin.

Table 2: Effect of Ethanol Leaf Extract of Hymenocardia acida on Pentylenetetrazole (PTZ) Induced Seizure in Mice

\begin{tabular}{lllll}
\hline $\begin{array}{l}\text { Treatment } \\
(\mathrm{mg} / \mathrm{kg})\end{array}$ & $\begin{array}{c}\text { \% Protection } \\
\text { seizure }(\mathrm{min})\end{array}$ & Mean onset of & $\begin{array}{c}\text { \% Mortality } \\
\text { death }(\mathrm{min})\end{array}$ & Mean latency to \\
\hline NS $10 \mathrm{ml} / \mathrm{kg}$ & 0.0 & $4.5 \pm 0.8$ & 100.0 & $5.8 \pm 0.8$ \\
ELHA $(250)$ & 0.0 & $6.3 \pm 0.9$ & 66.7 & $9.5 \pm 0.9$ \\
ELHA $(500)$ & 33.3 & $4.5 \pm 0.9$ & 66.7 & $7.0 \pm 1.6$ \\
ELHA (1000) & 0.0 & $7.8 \pm 1.7$ & 66.7 & $7.5 \pm 1.8$ \\
SV (200) & 66.7 & $8.0 \pm 4.0^{*}$ & 16.7 & $16.5 \pm 12.5^{* *}$
\end{tabular}

Values presented as Mean \pm SEM and percentages, ${ }^{*} \mathrm{P}<0.05,{ }^{* *} \mathrm{P}<0.01$ compared to normal saline group using One way ANOVA followed by Dunnett's post hoc, $n=6$, NS- Normal Saline, ELHA- Ethanol leaf extract of Hymenocardia acida, SV- Sodium Valproate.

Table 3: Effect of Ethanol Leaf Extract of Hymenocardia acida on 4- aminopyridine Induced Seizure in Mice

\begin{tabular}{|c|c|c|c|}
\hline $\begin{array}{l}\text { Treatment } \\
(\mathrm{mg} / \mathrm{kg})\end{array}$ & $\%$ Protection & $\begin{array}{l}\text { Mean onset of } \\
\text { seizure }(\min )\end{array}$ & \% Mortality \\
\hline NS $10 \mathrm{ml} / \mathrm{kg}$ & 0.0 & $11.0 \pm 1.1$ & 100.0 \\
\hline ELHA (250) & 50.0 & $16.3 \pm 1.5$ & 50.0 \\
\hline ELHA (500) & 50.0 & $12.3 \pm 0.9$ & 50.0 \\
\hline ELHA (1000) & 33.3 & $19.0 \pm 2.7^{* *}$ & 66.7 \\
\hline PHEB (20) & 100.0 & $0.0 \pm 0.0$ & 0.0 \\
\hline
\end{tabular}

Table 4: Effect of Ethanol Leaf Extract of Hymenocardia acida on Strychnine Induced Convulsion in Mice

\begin{tabular}{cccl}
$\begin{array}{c}\text { Treatment } \\
(\mathrm{mg} / \mathrm{kg})\end{array}$ & \% Protection & $\begin{array}{c}\text { Mean onset of } \begin{array}{c}\text { \% Mrtality } \\
\text { seizure }(\min )\end{array} \\
\text { NS 10 ml/kg }\end{array}$ & \multicolumn{3}{c}{$7.2 \pm 1.2$} & 83.3 \\
ELHA $(250)$ & 16.7 & $9.8 \pm 1.7$ & 83.3 \\
ELHA (500) & 16.7 & $9.8 \pm 1.5$ & 100.0 \\
ELHA (1000) & 0.0 & $8.8 \pm 1.4$ & 83.3 \\
PHEB (20) & 16.7 & $0.0 \pm 0.0$ & 0.0
\end{tabular}

Values presented as Mean \pm SEM and percentages, onset of seizure( treated groups) was compared to normal saline group using One way ANOVA followed by Dunnett's post hoc, $n=6$, NS- Normal Saline, ELHA- Ethanol leaf extract of Hymenocardia acida, PHEB- Phenobarbitone. 


\section{CONCLUSSION}

The results of this study suggest that the ethanol leaf extract of Hymenocardia acida contain phytochemical constituents that

\section{REFERENCES}

Browning, R. (1992). The electroshock model, neuronal network and antiepileptic drugs In: Faingold, C.L., and Fromm, G.H. (Eds) Drugs For Control Of Epilepsy: Actions On Neuronal Networks In Seizure Disorders, CRC Press, Boca Raton, F.L., 22:195-211.

Corbett, J.R., Wright, K. and Baillie, A. C. (1984). The Biochemical Mode of Action of Pesticides, second edition, Academic press, London and New York: 95-335.

Dalziel, J.M. (1937). Useful plants of Tropical West Africa. Crown Agent for Overseas Government and Administration. London pp153.

Kavvadias, D., Sand, P., Youdim, K.A., Qaiser, M.z., Rice- Evans, C., Baur, E. and Schreier, P. (2004). The Flavone hispidulin, a Benzodiazepine Receptor Ligand with Positive Allosteric Properties, Traverses the Blood Brain Barrier and Exhibit Anticonvulsant Effects. British journal of pharmacology, 142: 811-820.

Matsumara, F. (1975). Toxicology of Insecticides. Plenum Press, New York, Pp. 24-26. possess anticonvulsant action. This could explain Ethnomedicinal use of the plant in the treatment of epilepsy.

Porter, R.J., Cereghino, J.J. and Gladding, G.D. (1984). Antiepileptic Drug Eevelopment program. Cleve Clinical Quarterly, 51: 293-305.

Sayin, U., Cengiz, S. and Altug, T. (1993). Vigabatrin as an Anticonvulsant Against Pentylenetetrazole Seizures, Pharmacological Research, 28: 325-331.

Swinyard, E.A. and Kupferberg, H.J. (1985). Antiepileptic Drugs: Detection, Quantification and Evaluation. Federal Proceedings, 44: 39-43.

Swinyard, E.A., Woodhead, J.H., White, H.S. and Franklin, M.R. (1989). General Principles: Experimental Selection, Quantification, and Evaluation of Anticonvulsants. In: Levy, R.H., Mattson, B., Meldrum, J.K. and Dreifuss, F.E. (Eds) Antiepileptic Drugs, ( $3^{\text {rd }}$ ed.). Raven Press. New York. Pp. 85-103.

WHO (2016). Epilepsy: WHO Fact Sheets. Retrieved 22nd May 2016

Wickenden, A.D. (2002). Potassium channels as antiepileptic drug targets. Neuropharmacology, 43: 1055-1060.

Yamaguchi, S., and Rogawski, M.A. (1992). Effects of Anticonvulsant Drugs on 4aminopyridine-Induced Seizures in Mice. Epilepsy Research, 11 (1): 9-16. 